\title{
Thalassobacillus devorans gen. nov., sp. nov., a moderately halophilic, phenol-degrading, Gram-positive bacterium
}

\author{
María Teresa García, Virginia Gallego, Antonio Ventosa \\ and Encarnación Mellado \\ Department of Microbiology and Parasitology, Faculty of Pharmacy, University of Sevilla, Sevilla, \\ Spain
}

Correspondence

Encarnación Mellado

emellado@us.es

\begin{abstract}
A novel moderately halophilic bacterium, strain $\mathrm{G}-19.1^{\top}$, has been isolated from a phenol enrichment of samples collected in hypersaline habitats of southern Spain. This enrichment culture was a part of a screening programme to isolate halophilic bacteria able to degrade various aromatic compounds. Strain $\mathrm{G}-19.1^{\top}$ has been characterized as a potential phenol-degrader over a wide range of saline conditions. Strain G-19.1 ${ }^{\top}$ was found to be an aerobic, Gram-positive, endospore-forming, non-pigmented, moderately halophilic rod that grew optimally in media containing $7 \cdot 5-10 \% \mathrm{NaCl}$ at $\mathrm{pH} 7 \cdot 0$. The DNA G $+\mathrm{C}$ content was $42 \cdot 4 \mathrm{~mol} \%$. Phylogenetic analysis based on comparison of 16S rRNA gene sequences indicated that the closest relatives were Halobacillus species (96.2-97·0\%), although this novel isolate constitutes a separate line of descent within the radiation of Gram-positive rods. The cell-wall peptidoglycan contained meso-diaminopimelic acid, indicating that this strain does not share the main characteristic that differentiates members of the genus Halobacillus (which contain Orn-D-Asp) from other related genera. The predominant cellular fatty acids were anteiso- $C_{15: 0}$, iso- $C_{16: 0}$ and iso- $C_{15: 0}$. On the basis of phenotypic, genotypic and phylogenetic analyses, this isolate should be classified in a novel genus and species, for which the name Thalassobacillus devorans gen. nov., sp. nov. is proposed. The type strain is strain G-19.1 $1^{\top}\left(=\mathrm{DSM} 16966^{\top}=\mathrm{CECT} 7046^{\top}=\mathrm{CCM} 7282^{\top}\right)$.
\end{abstract}

Aromatic hydrocarbons from both natural and anthropogenic sources are abundant organic compounds in saline habitats. Because of environmental problems, various approaches designed to eliminate or reduce the presence of aromatic hydrocarbons have been pursued using bioremediation processes. However, the presence of salt constitutes a problem in bioremediation programmes in these contaminated habitats, constituting a limiting factor in such processes (Oren et al., 1992). In this respect, the study of halophilic communities able to degrade aromatic compounds over a wide range of salinities is of great importance and will help in the characterization and identification of novel efficient pollutant-degrading micro-organisms.

Halophilic communities in saline and hypersaline

Published online ahead of print on 22 April 2005 as DOI 10.1099/ ijs.0.63560-0.

Abbreviation: $m$-Dpm, $m$-diaminopimelic acid.

The GenBank/EMBL/DDBJ accession number for the 16S rRNA gene sequence of strain G-19.1 $1^{\top}$ is AJ717299.

Maximum-likelihood and maximum-parsimony trees are available as supplementary figures in IJSEM Online. environments are composed of species that fall mainly into two physiological groups, the extremely halophilic and the moderately halophilic bacteria and archaea (Ventosa et al., 1998), representing a promising ecosystem for biodegradation purposes. In recent years, efforts have been made to isolate halophilic bacteria able to degrade aromatic compounds (Margesin \& Schinner, 2001; Mellado \& Ventosa, 2003). However, little progress has been made in identifying the strains isolated. Of the moderately halophilic bacteria, a few members of the genera Halomonas, Marinobacter and Arhodomonas have been described as species able to degrade organic compounds (Adkins et al., 1993; Muñoz et al., 2001; Alva \& Peyton, 2003; Nicholson \& Fathepure, 2004; García et al., 2004; Huu et al., 1999; Hedlund et al., 2001). Less well known is the capacity of Gram-positive halophilic bacteria to degrade aromatic compounds, although other Gram-positive, non-halophilic genera are associated with degradation of these compounds, including both high-G $+\mathrm{C}$ Gram-positive bacteria, such as species of the genera Rhodococcus (Rast et al., 1980; Grund et al., 1992; Briglia et al., 1996; Eulberg et al., 1997; Yoon et al., 2000a, b), Arthrobacter (Eck \& Belter, 1993; Westerberg et al., 2000) and Microbacterium (Arrault et al., 2002; Gauthier et al., 2003), and low-G + C Gram-positive 
bacteria, such as species of the genus Bacillus (Zhuang et al., 2002; Yumoto et al., 2003).

For a long time, the group formed by the moderately halophilic, Gram-positive, endospore-forming bacteria was very limited and most of these micro-organisms were assigned to the genus Bacillus (Slepecky \& Hemphill, 1991). However, in recent years a number of novel genera and species have been described, such as the genus Halobacillus, which accommodates six species. This genus includes Gram-positive, spore-forming, moderately halophilic, motile bacteria possessing peptidoglycan of the Orn-DAsp type. The type species of the genus is Halobacillus halophilus, previously described as Sporosarcina halophila (Claus et al., 1983; Ventosa et al., 1983); the other Halobacillus species are Halobacillus trueperi, H. litoralis (Spring et al., 1996), H. karajensis (Amoozegar et al., 2003), H. salinus (Yoon et al., 2003) and H. locisalis (Yoon et al., 2004). In addition to species belonging to the genus Halobacillus, other spore-forming and halophilic species are found within the genera Virgibacillus (Heyndrickx et al., 1999; Heyrman et al., 2003), Gracilibacillus (Wainø et al., 1999), Filobacillus (Schlesner et al., 2001), Jeotgalibacillus (Yoon et al., 2001), Lentibacillus (Yoon et al., 2002; Namwong et al., 2005; Jeon et al., 2005), Pontibacillus (Lim et al., 2005a, b) and Tenuibacillus (Ren \& Zhou, 2005).

Recently, we characterized an active and acclimatized bacterial population able to degrade aromatic compounds in saline habitats in southern Spain. In this study, we isolated several strains that represented the dominant, culturable, moderately halophilic bacteria by using an enrichment culture method previously used for phenol and $p$-coumaric acid (García et al., 2004). For the enrichment strategy, cultures of sterile modified mineral medium M63 [KOH, $0.075 \mathrm{M} ; \mathrm{KH}_{2} \mathrm{PO}_{4}, 0.1 \mathrm{M} ;\left(\mathrm{NH}_{4}\right)_{2} \mathrm{SO}_{4}, 0.015 \mathrm{M} ; 1 \%(\mathrm{v} / \mathrm{v})$ $\mathrm{MgSO}_{4} / \mathrm{FeSO}_{4}$ solution $\left.\left(\mathrm{MgSO}_{4}, 1.6 \mathrm{mM} ; \mathrm{FeSO}_{4}, 39 \mu \mathrm{M}\right)\right]$ (Cohen \& Rickenberg, 1956) supplemented with $10 \% \mathrm{NaCl}$ and $0.005 \%$ yeast extract were used. Phenol was added to this medium at a concentration of $0.05 \%(\mathrm{w} / \mathrm{v})$. Enrichments were incubated at $37^{\circ} \mathrm{C}$ in a shaker incubator at 200 r.p.m. After 4 days incubation, $1 \mathrm{ml}$ enrichment was transferred into fresh medium and the medium was reincubated. Bacterial growth was monitored by observing increasing turbidity of the medium. After three successive transfers, the enriched cultures were plated on a solid version (18 g agar $\mathrm{l}^{-1}$ ) of modified M63 medium and incubated at $37^{\circ} \mathrm{C}$. A negative control containing no substrate was also included. Each individual colony was again checked for its ability to grow on phenol, after inoculation in the liquid selective medium described previously.

The enrichment procedure selected a limited number of fast-growing, phenol-degrading bacteria, which were mainly Gram-negative. However, a Gram-positive, rod-shaped strain, G-19.1 ${ }^{\mathrm{T}}$, showing a high level of degradative activity was isolated. The aim of the present study is to unravel the taxonomic and phylogenetic status of $\mathrm{G}-19.1^{\mathrm{T}}$, using a combination of phenotypic and phylogenetic analyses. To our knowledge, this is the first Gram-positive, moderately halophilic, phenol-degrading bacterium to be subjected to phylogenetic analysis.

The isolate was routinely grown on a complex saline medium (SW) with a final concentration of $10 \%(\mathrm{w} / \mathrm{v})$ total salts (SW-10) supplemented with $0 \cdot 5 \%(\mathrm{w} / \mathrm{v})$ yeast extract (Nieto et al., 1989). The strain was cultivated at $37^{\circ} \mathrm{C}$ in an orbital shaker (New Brunswick Scientific) at 200 r.p.m. When necessary, solid medium was prepared by adding $20 \mathrm{~g}$ Bacto agar $1^{-1}$ (Difco).

Strain G-19.1 ${ }^{\mathrm{T}}$ was examined for a range of phenotypic properties using standard procedures (Ventosa et al., 1982; Quesada et al., 1984; García et al., 1987). Cells of strain G-19.1 ${ }^{\mathrm{T}}$ were found to be Gram-positive rods that were oxidase-negative, catalase-positive and strictly aerobic. On $\mathrm{SW}-10$ medium incubated at $37^{\circ} \mathrm{C}$ for $48 \mathrm{~h}$, the strain produced cream-coloured, circular, convex and uniformly round colonies with a diameter of 1-2 mm. Ellipsoidal endospores were observed in a central position. No pigment was produced in the medium. Most species of the genus Halobacillus are characterized by their orange-pigmented colonies (Spring et al., 1996; Yoon et al., 2003, 2004). In contrast to species of Halobacillus, strain G-19.1 ${ }^{\mathrm{T}}$ does not produce orange colonies, is negative for oxidase and is able to reduce nitrate to nitrite. Several other features that distinguish strain G-19.1 ${ }^{\mathrm{T}}$ from its close phylogenetic relatives are shown in Table 1.

The salt requirements of strain G-19.1 ${ }^{\mathrm{T}}$ were determined in the complex medium SW with different salt concentrations: optimal growth occurred in media containing $7 \cdot 5$ $10 \%(\mathrm{w} / \mathrm{v})$ salt, although growth occurs in a wide range of salinities (from 0.5 to $20 \%$, w/v, salt). No growth was observed in the absence of $\mathrm{NaCl}$.

The nutritional features of $\mathrm{G}-19.1^{\mathrm{T}}$ were determined by using GP MicroPlates (Biolog). Strains were grown on isolate medium (Biolog) at $37^{\circ} \mathrm{C}$ for $24 \mathrm{~h}$. Suspensions of the strains were made using sterile saline medium $(3 \%$ $\mathrm{NaCl})$. Immediately after the cells had been suspended in the saline solution, Biolog GP MicroPlates were inoculated and incubated at $37^{\circ} \mathrm{C}$ for $24 \mathrm{~h}$. The results were read with a MicroPlate Reader using MICROLOG 3.59 computer software to perform automated reading. The results of the nutritional tests are given in the species description.

Genomic DNA was prepared using the method described by Marmur (1961). A PCR was carried out for the amplification of the almost-complete $16 \mathrm{~S}$ rRNA gene (1506 bp) by using primers 16F27 and 16R1488 (Mellado et al., 1995). Sequencing was performed using an automated DNA sequencer (model 3100; Applied Biosystems). The DNA sequences were analysed using the ARB software package (Ludwig \& Strunk, 1996). The 16S rRNA gene sequences were aligned and the alignment confirmed and checked against both primary and secondary structure of 
Table 1. Characteristics useful for distinguishing Thalassobacillus devorans gen. nov., sp. nov. from related taxa

Taxa: 1, Thalassobacillus devorans; 2, Halobacillus; 3, Virgibacillus; 4, Gracilibacillus; 5, Filobacillus; 6, B. haloalkaliphilus DSM 5271 ${ }^{\mathrm{T}}$; 7 , Lentibacillus; 8, Pontibacillus; 9, Tenuibacillus. Data are from Spring et al. (1996), Amoozegar et al. (2003), Yoon et al. (2002, 2003, 2004), Heyndrickx et al. (1999), Heyrman et al. (2003), Wainø et al. (1999), Schlesner et al. (2001), Fritze (1996), Namwong et al. (2005), Jeon et al. (2005), Lim et al. (2005a, b), Ren \& Zhou (2005) and this study. Symbols: +, positive; -, negative; V, variable; W, weakly positive; $\mathrm{ND}$, not determined.

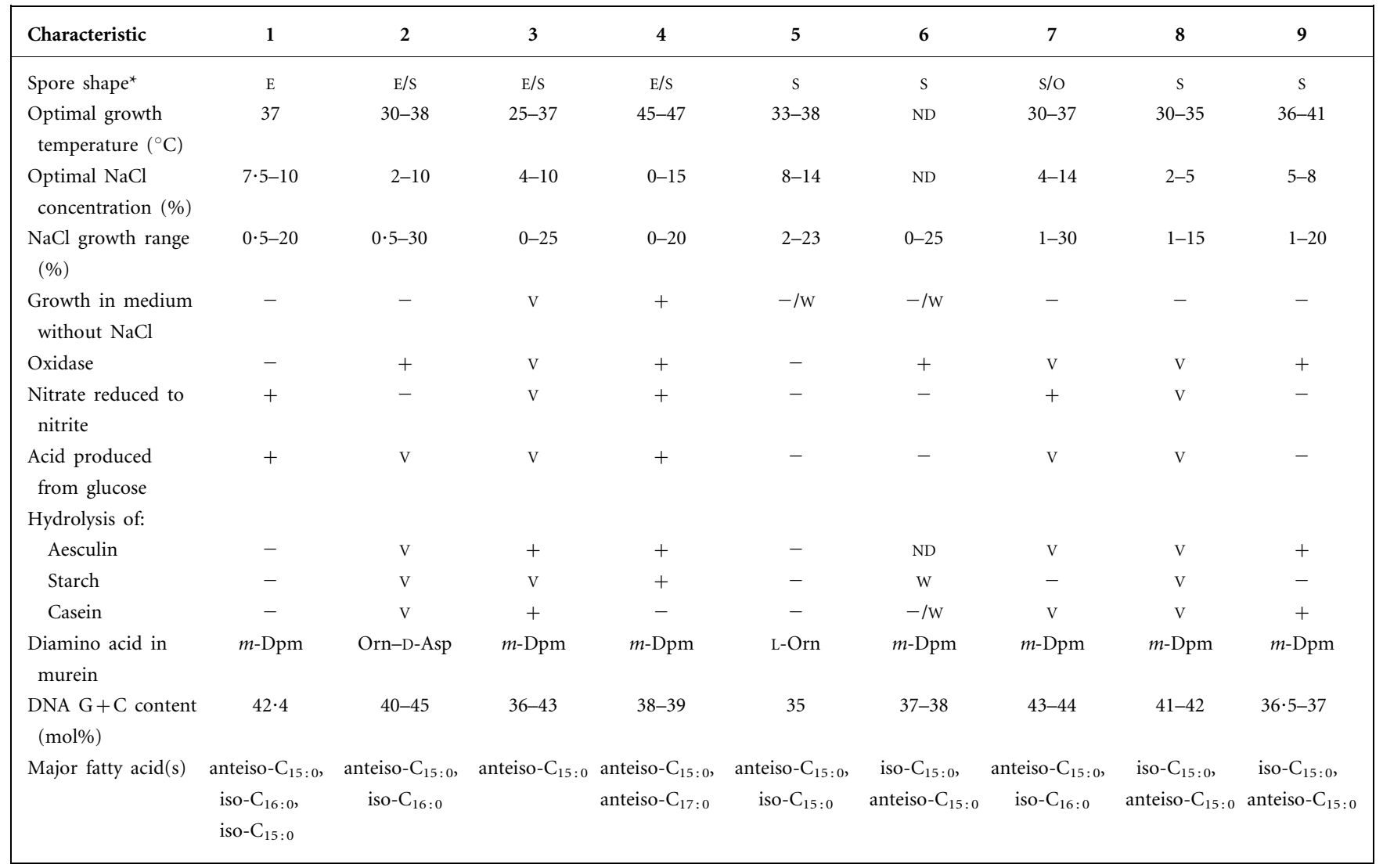

${ }^{\star}$ E, Ellipsoidal; S, spherical; O, oval.

the 16S rRNA molecule by using the alignment tool of the ARB software package. The aligned sequences were subjected to different phylogenetic methods integrated into the ARB software for phylogenetic inference. These methods included maximum-likelihood (Felsenstein, 1981), maximum-parsimony (Kluge \& Farris, 1969) and neighbour-joining (Saitou \& Nei, 1987) procedures. Basefrequency filters were applied in the sequence comparison analysis and the effects on the results evaluated.

A comparison using $16 \mathrm{~S}$ rRNA gene sequences available in the databases revealed that the 16S rRNA gene sequence of strain G-19.1 ${ }^{\mathrm{T}}$ displays a high level of similarity to those from Halobacillus species with validly published names (96-2-97.0\% sequence similarity). Other spore-forming and halophilic or halotolerant taxa (Virgibacillus, Gracilibacillus, Lentibacillus and Pontibacillus species, Filobacillus milensis, Bacillus haloalkaliphilus and Tenuibacillus multivorans) were more distantly related to strain G-19.1 ${ }^{\mathrm{T}}$, displaying $16 \mathrm{~S}$ rRNA gene sequence similarity below $95 \%$.
In the tree based on the neighbour-joining algorithm (Saitou \& Nei, 1987), strain G-19.1 $1^{\mathrm{T}}$ falls within the radiation of the cluster comprising members of the genus Halobacillus, but emerges as a separate entity. These results are congruent with those obtained using the maximum-likelihood and maximum-parsimony algorithms. The neighbour-joining tree in Fig. 1 shows the relationship between strain G$19.1^{\mathrm{T}}$ and the other species of the genus Halobacillus and other related bacteria. Maximum-likelihood and maximumparsimony trees are available as supplementary figures in IJSEM Online.

The genotypic relatedness between isolate $\mathrm{G}-19.1^{\mathrm{T}}$ and phylogenetically closely related species was determined by DNA-DNA hybridization. These studies were carried out by following the competition procedure of Johnson (1994), described in detail in Mormile et al. (1999). The levels of DNA-DNA hybridization between strain G-19.1 ${ }^{\mathrm{T}}$ and the phylogenetically related Halobacillus species were low and, in any case, below $70 \%$ (H. trueperi DSM $10404^{\mathrm{T}}, 32 \%$; 


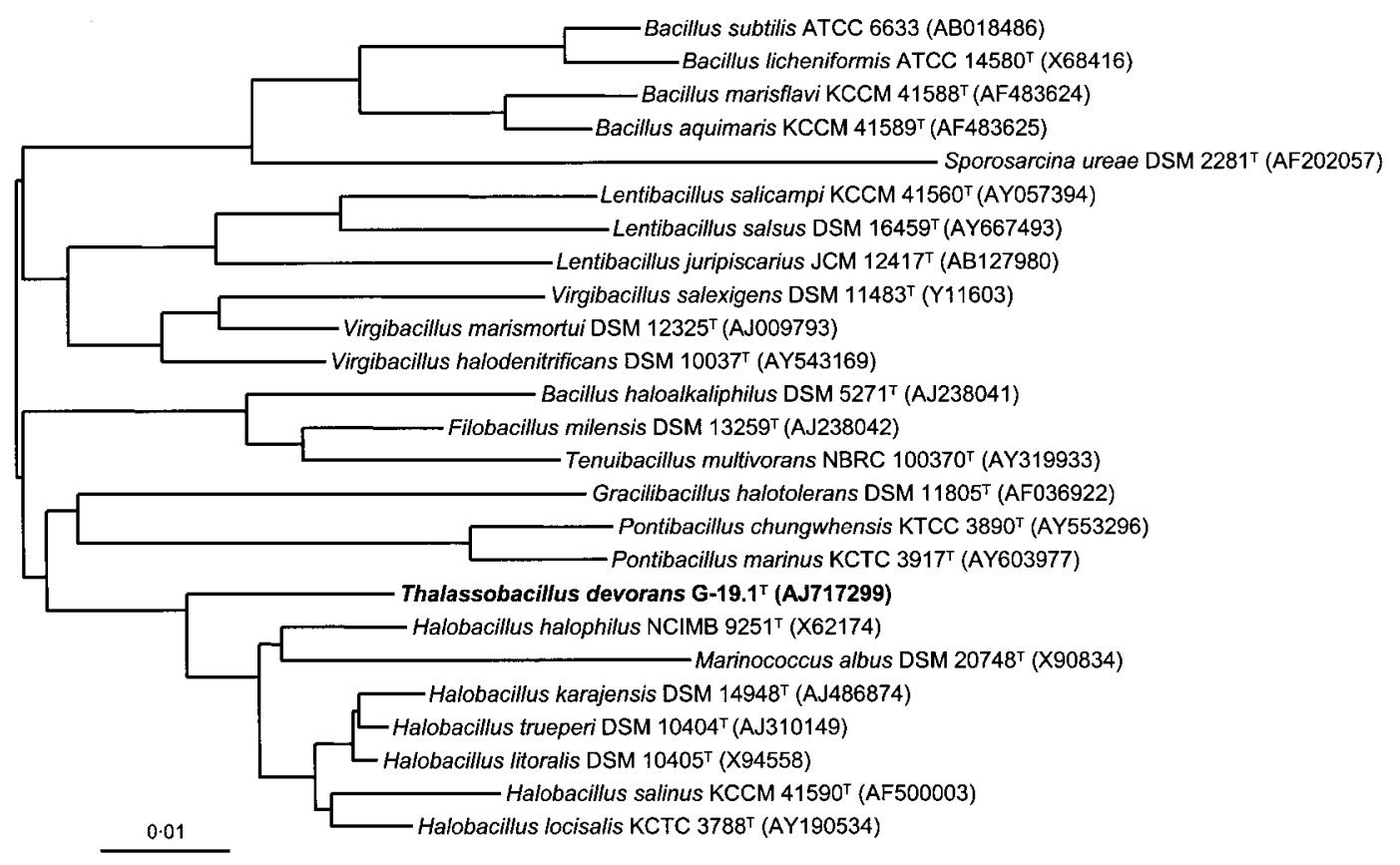

Fig. 1. Neighbour-joining tree, based on $16 \mathrm{~S}$ rRNA gene sequence comparison, showing the phylogenetic position of Thalassobacillus devorans G-19.1 ${ }^{\top}$ among representatives of some other related Gram-positive bacteria. The accession numbers of the sequences used in this study are shown in parentheses. Bar, $1 \%$ sequence divergence.

H. litoralis DSM $10405^{\mathrm{T}}, 13 \%$; H. salinus KCCM $41590^{\mathrm{T}}$, $31 \%$; H. karajensis DSM $14948^{\mathrm{T}}, 25 \%$ ), providing decisive evidence that strain $\mathrm{G}-19.1^{\mathrm{T}}$ is not genotypically related to the Halobacillus species tested.

The G $+\mathrm{C}$ content of the genomic DNA, determined by using the method of Marmur \& Doty (1962) with the equation of Owen \& Hill (1979), was $42 \cdot 4 \mathrm{~mol} \%$.

The cell-wall peptidoglycan was analysed according to Schleifer \& Kandler (1972) by the Deutsche Sammlung von Mikroorganismen und Zellkulturen GmbH (DSMZ, Braunschweig, Germany). The analysis showed that strain G-19.1 ${ }^{\mathrm{T}}$ possessed peptidoglycan type A1 $\gamma$ with $m$ diaminopimelic acid $(m$-Dpm) as the diagnostic diamino acid. The major isoprenoid quinone was MK-7. The cellular fatty acids of strain G-19.1 ${ }^{\mathrm{T}}$ were analysed with the MIDI system (Microbial ID). Cells were cultured in SW-7.5 medium (Ventosa et al., 1982) at $37^{\circ} \mathrm{C}$ for $24 \mathrm{~h}$. The predominant fatty acids of strain G-19.1 ${ }^{\mathrm{T}}$ were anteiso$\mathrm{C}_{15: 0}(52 \cdot 3 \%)$, iso- $\mathrm{C}_{16: 0}(10 \cdot 5 \%)$, iso- $\mathrm{C}_{15: 0}(10 \cdot 2 \%)$, anteiso- $\mathrm{C}_{17: 0}(8 \cdot 3 \%)$, anteiso- $\mathrm{C}_{17: 1}(5 \cdot 1 \%)$ and iso- $\mathrm{C}_{14: 0}$ $(4 \cdot 8 \%)$. Strain G-19.1 $1^{\mathrm{T}}$ and the phylogenetically related genera contained similar fatty acid profiles, having anteiso$\mathrm{C}_{15: 0}$ as a major fatty acid (Table 1 ).

Overall, our results showed that strain G-19.1 ${ }^{\mathrm{T}}$ exhibited the closest phylogenetic affiliation to Halobacillus species; however, comparative 16S rRNA gene sequence analysis showed that this strain represents a novel branch within the category of Gram-positive spore-forming rods. A cell-wall type based on Orn-D-Asp constitutes a key characteristic that differentiates members of the genus Halobacillus from other phylogenetically related genera of endospore-forming rods (Arahal \& Ventosa, 2000). The results obtained in our chemotaxonomic analysis, revealing a cell-wall type based on $m$-Dpm, support the conclusion that strain G-19.1 ${ }^{\mathrm{T}}$ cannot be assigned to the genus Halobacillus. In addition, some phenotypic features differentiate isolate $\mathrm{G}-19.1^{\mathrm{T}}$ from species of Halobacillus (Table 1), a genus that was defined as being oxidase-positive and unable to reduce nitrate to nitrite (Spring et al., 1996), two features that differ from those of strain G-19.1 ${ }^{\mathrm{T}}$.

Strain $\mathrm{G}-19.1^{\mathrm{T}}$ was phylogenetically related at a $16 \mathrm{~S}$ rRNA gene sequence similarity level below $95 \%$ to other genera with a cell-wall type based on $m$-Dpm. In addition, some chemotaxonomic and phenotypic features differentiate isolate G-19.1 ${ }^{\mathrm{T}}$ from phylogenetically related sporeforming taxa (Table 1). Strain G-19.1 ${ }^{\mathrm{T}}$ is oxidase-negative, whereas other related $m$-Dpm-containing genera, such as Gracilibacillus and Tenuibacillus, are described as being oxidase-positive. The genus Filobacillus is defined as being oxidase-negative, like strain G-19.1 ${ }^{\mathrm{T}}$; however, this genus does not reduce nitrate to nitrite, a characteristic that is useful for differentiating it from strain $\mathrm{G}-19.1^{\mathrm{T}}$. Members of other related $m$-Dpm-containing genera such as Gracilibacillus, Virgibacillus and Tenuibacillus hydrolyse aesculin, unlike strain G-19.1 .

Overall, the phenotypic, genotypic and phylogenetic 
analyses performed suggested that strain G-19.1 ${ }^{\mathrm{T}}$ cannot be assigned to any known taxon. We therefore propose to classify this novel isolate in a novel genus and species separate from all $m$-Dpm-containing bacilli as well as the genus Halobacillus, for which the name Thalassobacillus devorans gen. nov., sp. nov. is proposed.

\section{Description of Thalassobacillus gen. nov.}

Thalassobacillus (Tha.las'so.ba.cil'lus. Gr. fem. n. thalassa sea; L. masc. n. bacillus rod; N.L. masc. n. Thalassobacillus rod from the sea).

Gram-positive, spore-forming, rod-shaped cells. Motile. Catalase-positive, oxidase-negative and urease-negative. Nitrate is reduced to nitrite. Ellipsoidal endospores in central position. Moderately halophilic: does not grow in media without $\mathrm{NaCl}$. Cell-wall peptidoglycan type $\mathrm{A} 1 \gamma$ with $m$-Dpm. Major fatty acids are anteiso- $\mathrm{C}_{15: 0}$, iso- $\mathrm{C}_{16: 0}$ and iso- $\mathrm{C}_{15: 0}$. Predominant menaquinone is MK-7. The $\mathrm{G}+\mathrm{C}$ content of the DNA of the type species is $42.4 \mathrm{~mol} \%$. The type species is Thalassobacillus devorans.

\section{Description of Thalassobacillus devorans sp. nov.}

Thalassobacillus devorans [de.vo'rans. L. v. devorare to devour; L. part. adj. devorans devouring (organic compounds)].

Cells are $2 \cdot 0-4 \cdot 0 \times 1 \cdot 0-1 \cdot 2 \mu \mathrm{m}$. Motile by means of flagella. Colonies are uniformly round, circular, regular, convex and cream-coloured on SW-10 medium. Moderately halophilic, growing in a wide range $(0 \cdot 5-20 \%, \mathrm{w} / \mathrm{v})$ of salt concentrations, with optimum growth at $7 \cdot 5-10 \%(\mathrm{w} / \mathrm{v})$ salts. No growth in the absence of $\mathrm{NaCl}$. No other salt requirements determined. Growth occurs at $15-45^{\circ} \mathrm{C}$ (optimal temperature $37^{\circ} \mathrm{C}$ ) and at pH $6 \cdot 0-10 \cdot 0$ (optimal pH is $7 \cdot 0$ ). Strictly aerobic. Aesculin is not hydrolysed. Indole, methyl red and Voges-Proskauer tests are negative. Gelatin and Tween 80 are hydrolysed. Starch and casein are not hydrolysed. Acid is produced from D-glucose, D-trehalose, D-mannose and D-fructose. As determined by the Biolog GP panel, the following compounds are utilized: dextrin, $N$-acetyl-Dglucosamine, $N$-acetyl-D-mannosamine, D-fructose, $\alpha$-Dglucose, maltose, maltotriose, D-mannitol, D-mannose, D-melezitose, 3-methyl glucose, palatinose, D-psicose, Dsorbitol, sucrose, D-trehalose, acetic acid, $\beta$-hydroxybutyric acid, $\alpha$-ketovaleric acid, pyruvic acid, thymidine and uridine. The following compounds are not utilized as sole carbon and energy sources (Biolog): $\alpha$-cyclodextrin, $\beta$ cyclodextrin, glycogen, inulin, mannan, Tweens 40 and 80 , amygdalin, L-arabinose, D-arabitol, arbutin, cellobiose, L-fucose, D-galactose, D-galacturonic acid, gentiobiose, D-gluconic acid, myo-inositol, $\alpha$-D-lactose, lactulose, Dmelibiose, methyl $\alpha$-D-galactoside, methyl $\beta$-D-galactoside, methyl $\alpha$-D-glucoside, methyl $\beta$-D-glucoside, methyl $\alpha$-D-mannoside, D-raffinose, L-rhamnose, D-ribose, salicin, sedoheptulosan, stachyose, D-tagatose, turanose, xylitol, D-xylose, $\alpha$-hydroxybutyric acid, $\gamma$-hydroxybutyric acid, $p$-hydroxyphenylacetic acid, $\alpha$-ketoglutaric acid, lactamide, D-lactic acid methyl ester, L-lactic acid, D-malic acid, L-malic acid, methyl pyruvate, monomethyl succinate, propionic acid, succinamic acid, succinic acid, $\mathrm{N}$ acetyl-L-glutamic acid, alaninamide, D-alanine, L-alanine, L-alanyl glycine, L-asparagine, L-glutamic acid, glycyl Lglutamic acid, L-pyroglutamic acid, L-serine, putrescine, 2,3-butanediol, glycerol, adenosine, 2'-deoxyadenosine, inosine, adenosine $5^{\prime}$-monophosphate, thymidine $5^{\prime}$ monophosphate, uridine $5^{\prime}$-monophosphate, fructose 6phosphate, glucose 1-phosphate, glucose 6-phosphate and $\alpha$-DL-glycerol phosphate. Other characteristics as for the genus. The DNA $\mathrm{G}+\mathrm{C}$ content of the type strain is $42 \cdot 4 \mathrm{~mol} \%$.

The type strain, G-19.1 ${ }^{\mathrm{T}} \quad\left(=\mathrm{DSM} \quad 16966^{\mathrm{T}}=\mathrm{CECT}\right.$ $7046^{\mathrm{T}}=\mathrm{CCM} 7282^{\mathrm{T}}$ ), was isolated from a saline soil in southern Spain.

\section{Acknowledgements}

This work was supported by grants from the Spanish Ministerio de Ciencia y Tecnología (REN2003-01650 and BMC2003-1344) and Junta de Andalucía.

\section{References}

Adkins, J. P., Madigan, M. T., Mandelco, L., Woese, C. R. \& Tanner, R. S. (1993). Arhodomonas aquaeolei gen. nov., sp. nov., an aerobic, halophilic bacterium isolated from a subterranean brine. Int $J$ Syst Bacteriol 43, 514-520.

Alva, V. A. \& Peyton, B. M. (2003). Phenol and catechol biodegradation by the haloalkaliphile Halomonas campisalis: influence of pH and salinity. Environ Sci Technol 37, 4397-4402.

Amoozegar, M. A., Malekzadeh, F., Malik, K. A., Schumann, P. \& Spröer, C. (2003). Halobacillus karajensis sp. nov., a novel moderate halophile. Int J Syst Evol Microbiol 53, 1059-1063.

Arahal, D. R. \& Ventosa, A. (2000). Moderately halophilic and halotolerant species of Bacillus and related genera. In Applications and Systematics of Bacillus and Relatives, pp. 83-99. Edited by R. Berkeley, M. Heyndrickx, N. Logan \& P. De Vos. Oxford: Blackwell.

Arrault, S., Desaint, S., Catroux, C., Semon, E., Mougin, C. \& Fournier, J. C. (2002). Isolation and characterization of efficient isoxaben-transforming Microbacterium sp. strains from four European soils. Pest Manag Sci 58, 1229-1235.

Briglia, M., Rainey, F. A., Stackebrandt, E., Schraa, G. \& SalkinojaSalonen, M. S. (1996). Rhodococcus percolatus sp. nov., a bacterium degrading 2,4,6-trichlorophenol. Int J Syst Bacteriol 46, 23-30.

Claus, D., Fahmy, F., Rolf, H. J. \& Tosunoglu, N. (1983). Sporosarcina halophila sp. nov., an obligate, slightly halophilic bacterium from salt marsh soils. Syst Appl Microbiol 4, 496-506.

Cohen, G. N. \& Rickenberg, R. H. (1956). Concentration specifique reversible des amino acides chez E. coli. Ann Inst Pasteur 91, 693-720 (in French).

Eck, R. \& Belter, J. (1993). Cloning and characterization of a gene coding for the catechol 1,2-dioxygenase of Arthrobacter sp. mA3. Gene 123, 87-92. 
Eulberg, D., Golovleva, L. A. \& Schlömann, M. (1997). Characterization of catechol catabolic genes from Rhodococcus erythropolis 1CP. J Bacteriol 179, 370-381.

Felsenstein, J. (1981). Evolutionary trees from DNA sequences: a maximum likelihood approach. J Mol Evol 17, 368-376.

Fritze, D. (1996). Bacillus haloalkaliphilus sp. nov. Int J Syst Bacteriol 46, 98-101.

García, M. T., Ventosa, A., Ruiz-Berraquero, F. \& Kocur, M. (1987). Taxonomic study and amended description of Vibrio costicola. Int J Syst Bacteriol 37, 251-256.

García, M. T., Mellado, E., Ostos, J. C. \& Ventosa, A. (2004). Halomonas organivorans sp. nov., a novel moderate halophile able to degrade aromatic compounds. Int J Syst Evol Microbiol 54, 1723-1728.

Gauthier, E., Deziel, E., Villemur, R., Juteau, P., Lepine, F. \& Beaudet, R. (2003). Initial characterization of new bacteria degrading high-molecular weight polycyclic aromatic hydrocarbons isolated from a 2-year enrichment in a two-liquid-phase culture system. J Appl Microbiol 94, 301-311.

Grund, E., Denecke, B. \& Eichenlaub, R. (1992). Naphthalene degradation via salicylate and gentisate by Rhodococcus sp. strain B4. Appl Environ Microbiol 58, 1874-1877.

Hedlund, B. P., Geiselbrecht, A. D. \& Staley, J. T. (2001). Marinobacter strain NCE312 has a Pseudomonas-like naphthalene dioxygenase. FEMS Microbiol Lett 201, 47-51.

Heyndrickx, M., Lebbe, L., Kersters, K., Hoste, B., De Wachter, R., De Vos, P., Forsyth, G. \& Logan, N. A. (1999). Proposal of Virgibacillus proomii sp. nov. and emended description of Virgibacillus pantothenticus (Proom and Knight 1950) Heyndrickx et al. 1998. Int J Syst Bacteriol 49, 1083-1090.

Heyrman, J., Logan, N. A., Busse, H. J., Balcaen, A., Lebbe, L., Rodriguez-Diaz, M., Swings, J. \& De Vos, P. (2003). Virgibacillus carmonensis sp. nov., Virgibacillus necropolis sp. nov. and Virgibacillus picturae sp. nov., three novel species isolated from deteriorated mural paintings, transfer of the species of the genus Salibacillus to Virgibacillus, as Virgibacillus marismortui comb. nov. and Virgibacillus salexigens comb. nov., and emended description of the genus Virgibacillus. Int J Syst Evol Microbiol 53, 501-511.

Huu, N. B., Denner, E. B., Ha, D. T., Wanner, G. \& Stan-Lotter, H. (1999). Marinobacter aquaeolei sp. nov., a halophilic bacterium isolated from a Vietnamese oil-producing well. Int J Syst Bacteriol 49, 367-375.

Jeon, C. O., Lim, J.-M., Lee, J.-C., Lee, G. S., Lee, J.-M., Xu, L.-H., Jiang, C.-L. \& Kim, C.-J. (2005). Lentibacillus salarius sp. nov, isolated from saline sediment in China, and emended description of the genus Lentibacillus. Int J Syst Evol Microbiol 55, 1339-1343.

Johnson, J. L. (1994). Similarity analysis of DNAs. In Methods for General and Molecular Bacteriology, pp. 655-681. Edited by P. Gerhardt, R. G. E. Murray, W. A. Wood \& N. R. Krieg. Washington, DC: American Society for Microbiology.

Kluge, A. G. \& Farris, F. S. (1969). Quantitative phyletics and the evolution of anurans. Syst Zool 18, 1-32.

Lim, J.-M., Jeon, C. O., Song, S. M. \& Kim, C.-J. (2005a). Pontibacillus chungwhensis gen. nov., sp. nov., a moderately halophilic Grampositive bacterium from a solar saltern in Korea. Int J Syst Evol Microbiol 55, 165-170.

Lim, J.-M., Jeon, C. O., Park, D.-J., Kim, H.-R., Yoon, B.-J. \& Kim, C.-J. (2005b). Pontibacillus marinus sp. nov, a moderately halophilic bacterium from a solar saltern, and emended description of the genus Pontibacillus. Int J Syst Evol Microbiol 55, 1027-1031.

Ludwig, W. \& Strunk, O. (1996). ARB - a software environment for sequence data. http://www.arb-home.de/
Margesin, R. \& Schinner, F. (2001). Biodegradation and bioremediation of hydrocarbons in extreme environments. Appl Microbiol Biotechnol 56, 650-663.

Marmur, J. (1961). A procedure for the isolation of deoxyribonucleic acid from micro-organisms. J Mol Biol 3, 208-218.

Marmur, J. \& Doty, P. (1962). Determination of the base composition of deoxyribonucleic acid from its thermal denaturation temperature. J Mol Biol 5, 109-118.

Mellado, E. \& Ventosa, A. (2003). Biotechnological potential of moderately and extremely halophilic microorganisms. In Microorganisms for Health Care, Food and Enzyme Production, pp. 233256. Edited by J. L. Barredo. Kerala: Research Signpost.

Mellado, E., Moore, E. R. B., Nieto, J. J. \& Ventosa, A. (1995) Phylogenetic inferences and taxonomic consequences of $16 \mathrm{~S}$ ribosomal DNA sequence comparison of Chromohalobacter marismortui, Volcaniella eurihalina, and Deleya salina, and reclassification of V. eurihalina as Halomonas eurihalina comb. nov. Int J Syst Bacteriol 45, 712-716

Mormile, M. R., Romine, M. F., Garcia, M. T., Ventosa, A., Bailey, T. J. \& Peyton, B. M. (1999). Halomonas campisalis sp. nov., a denitrifying, moderately haloalkaliphilic bacterium. Syst Appl Microbiol 22, 551-558.

Muñoz, J. A., Perez-Esteban, B., Esteban, M., de la Escalera, S. Gomez, M. A., Martínez-Toledo, M. V. \& Gonzalez-Lopez, J. (2001). Growth of moderately halophilic bacteria isolated from sea water using phenol as the sole carbon source. Folia Microbiol 46, 297-302.

Namwong, S., Tanasupawat, S., Smitinont, T., Visessanguan, W., Kudo, T. \& Itoh, T. (2005). Isolation of Lentibacillus salicampi strains and Lentibacillus juripiscarius sp. nov. from fish sauce in Thailand. Int J Syst Evol Microbiol 55, 315-320.

Nicholson, C. A. \& Fathepure, B. Z. (2004). Biodegradation of benzene by halophilic and halotolerant bacteria under aerobic conditions. Appl Environ Microbiol 70, 1222-1225.

Nieto, J. J., Fernandez-Castillo, R., Marquez, M. C., Ventosa, A., Quesada, E. \& Ruiz-Berraquero, F. (1989). Survey of metal tolerance in moderately halophilic eubacteria. Appl Environ Microbiol 55, 2385-2390.

Oren, A., Gurevich, P., Azachi, M. \& Henis, Y. (1992). Microbial degradation of pollutants at high salt concentrations. Biodegradation 3, 387-398.

Owen, R. J. \& Hill, L. R. (1979). The estimation of base compositions, base pairing and genome size of bacterial deoxyribonucleic acids. In Identification Methods for Microbiologists, 2nd edn, pp. 217-296. Edited by F. A. Skinner \& D. W. Lovelock. London: Academic Press. Quesada, E., Ventosa, A., Ruiz-Berraquero, F. \& RamosCormenzana, A. (1984). Deleya halophila, a new species of moderately halophilic bacteria. Int J Syst Bacteriol 40, 261-267.

Rast, H. G., Engelhardt, G. \& Wallnoefer, P. R. (1980). Degradation of aromatic compounds in the actinomycete genus Rhodococcus. FEMS Microbiol Lett 7, 1-7.

Ren, P. G. \& Zhou, P. J. (2005). Tenuibacillus multivorans gen. nov., sp. nov., a moderately halophilic bacterium isolated from saline soil in Xin-Jiang, China. Int J Syst Evol Microbiol 55, 95-99.

Saitou, N. \& Nei, M. (1987). The neighbor-joining method: a new method for reconstructing phylogenetic trees. Mol Biol Evol 4, 406-425.

Schleifer, K. H. \& Kandler, O. (1972). Peptidoglycan types of bacterial cell walls and their taxonomic implications. Bacteriol Rev 36, 407-477.

Schlesner, H., Lawson, P. A., Collins, M. D., Weiss, N., Wehmeyer, U., Volker, H. \& Thomm, M. (2001). Filobacillus milensis gen. nov., 
sp. nov., a new halophilic spore-forming bacterium with Orn-D-Glutype peptidoglycan. Int J Syst Evol Microbiol 51, 425-431.

Slepecky, R. A. \& Hemphill, H. E. (1991). The genus Bacillus - nonmedical. In The Prokaryotes, pp. 1663-1696. Edited by A. Balows, H. G. Trüper, M. Dworkin, W. Harder \& K. H. Schleifer. New York: Springer.

Spring, S., Ludwig, W., Marquez, M. C., Ventosa, A. \& Schleifer, K. H. (1996). Halobacillus gen. nov., with descriptions of Halobacillus litoralis sp. nov. and Halobacillus trueperi sp. nov., and transfer of Sporosarcina halophila to Halobacillus halophilus comb. nov. Int J Syst Bacteriol 46, 492-496.

Ventosa, A., Quesada, E., Rodríguez-Valera, F., Ruiz-Berraquero, F. \& Ramos-Cormenzana, A. (1982). Numerical taxonomy of moderately halophilic Gram-negative rods. J Gen Microbiol 128, 1959-1968.

Ventosa, A., Ramos-Cormenzana, A. \& Kocur, M. (1983). Moderately halophilic Gram-positive cocci from hypersaline environments. Syst Appl Microbiol 4, 564-570.

Ventosa, A., Nieto, J. J. \& Oren, A. (1998). Biology of moderately halophilic aerobic bacteria. Microbiol Mol Biol Rev 62, 504-544.

Wainø, M., Tindall, B. J., Schumann, P. \& Ingvorsen, K. (1999). Gracilibacillus gen. nov., with description of Gracilibacillus halotolerans gen. nov., sp. nov.; transfer of Bacillus dipsosauri to Gracilibacillus dipsosauri comb. nov., and Bacillus salexigens to the genus Salibacillus gen. nov., as Salibacillus salexigens comb. nov. Int J Syst Bacteriol 49, 821-831.

Westerberg, K., Elvang, A. M., Stackebrandt, E. \& Jansson, J. K. (2000). Arthrobacter chlorophenolicus sp. nov., a new species capable of degrading high concentrations of 4-chlorophenol. Int J Syst Evol Microbiol 50, 2083-2092.
Yoon, J.-H., Cho, Y.-G., Kang, S.-S., Kim, S. B., Lee, S. T. \& Park, Y.-H. (2000a). Rhodococcus koreensis sp. nov. a 2,4-dinitrophenoldegrading bacterium. Int J Syst Evol Microbiol 50, 1193-1201.

Yoon, J.-H., Kang, S.-S., Cho, Y.-G., Lee, S. T., Kho, Y. H., Kim, C.-J. \& Park, Y.-H. (2000b). Rhodococcus pyridinivorans sp. nov., a pyridine-degrading bacterium. Int J Syst Evol Microbiol 50, 2173-2180.

Yoon, J. H., Weiss, N., Lee, K. C., Lee, I. S., Kang, K. H. \& Park, Y. H. (2001). Jeotgalibacillus alimentarius gen. nov., sp. nov., a novel bacterium isolated from jeotgal with L-lysine in the cell wall, and reclassification of Bacillus marinus Rüger 1983 as Marinibacillus marinus gen. nov., comb. nov. Int J Syst Evol Microbiol 51, 2087-2093.

Yoon, J. H., Kang, K. H. \& Park, Y. H. (2002). Lentibacillus salicampi gen. nov., sp. nov., a moderately halophilic bacterium isolated from a salt field in Korea. Int J Syst Evol Microbiol 52, 2043-2048.

Yoon, J. H., Kang, K. H. \& Park, Y. H. (2003). Halobacillus salinus sp. nov., isolated from a salt lake on the coast of the East Sea in Korea. Int J Syst Evol Microbiol 53, 687-693.

Yoon, J. H., Kang, K. H., Oh, T. K. \& Park, Y. H. (2004). Halobacillus locisalis sp. nov., a halophilic bacterium isolated from a marine solar saltern of the Yellow Sea in Korea. Extremophiles 8, 23-28.

Yumoto, I., Yamaga, S., Sogabe, Y., Nodasaka, Y., Matsuyama, H., Nakajima, K. \& Suemori, A. (2003). Bacillus krulwichiae sp. nov., a halotolerant obligate alkaliphile that utilizes benzoate and $\mathrm{m}$ hydroxybenzoate. Int J Syst Evol Microbiol 53, 1531-1536.

Zhuang, W. Q., Zhuang, W. Q., Maszenan, A. M. \& Tay, S. T. (2002). Bacillus naphthovorans sp. nov. from oil-contaminated tropical marine sediments and its role in naphthalene biodegradation. Appl Microbiol Biotechnol 58, 547-553. 